\title{
EFFECT OF MODERN APPLE PRODUCTION TECHNOLOGIES ON DEVELOPMENT OF FAMILY ORCHARD FARMING WITH PARTICULAR FOCUS ON POLISH CONDITIONS
}

\author{
Marek Gaworski, Wojciech Ciesielski, Natalia Kaminska \\ Warsaw University of Life Sciences, Warsaw, Poland \\ marek_gaworski@sggw.pl,wojciech.ciesielski1@interia.pl, natalia_kaminska@sggw.pl
}

\begin{abstract}
The aim of this paper was to present the effect of modern apple production technologies on the development of family orchard farming and possible savings in the farm's economic calculation. The state of the art concerning farming was presented to show the effect of the new technologies implemented and new technical equipment on fruit production efficiency as well as market competitiveness of the analysed farm. The investigations presented in the paper were carried out in the production and storage season of 2015/2016. New technical equipment was assessed including the index of technological level and economic balance, i.e. costs spent to equip the fruit farm with specialist machinery and tractors as well as the income and overall profit resulting from application of the new technical solutions. Moreover, the results of the experiment with apples in the orchard were presented. The experiment included two options: one part of fruit trees irrigated and the other part of fruit trees not irrigated. The structure of the picked up apples in the experiment was considered to find the effect of irrigation on the apple yield and possible profit / loss of the income from orchard production in case of farms equipped and not equipped with modern technologies of orchard irrigation.
\end{abstract}

Keywords: apple, orchard, equipment, production, technology.

\section{Introduction}

Orchard farming is one of the most dynamically developing agriculture sectors in Poland. This results from numerous factors, including access to the EU funds, which encourage fruit growers to invest in the development of their farms. Poland is the European leader in apple production and exports, with apple tree orchards occupying the area of approximately 198 thousand hectares and production volumes in fertile years as high as over 4 million tonnes of the fruit [1]. According to the Central Statistical Office data from September 2016, fruit production in Poland in 2016 reached 4.5 million tonnes compared to 4.1 million tonnes in the preceding year [2].

At present, profits and further development can only be achieved by farms characterised with low production costs and technologies allowing production of top quality fruit. Therefore, investments in new apple cultivation and storage technologies are necessary in order to be competitive and generate profits from the farm's production [3]. Only top quality apples are sought in the market and only top quality apples allow achievement of prices, which guarantee production profitability [4].

In order to successfully deal with and make decent profits from apple production in the $21^{\text {st }}$ century, production intensification is essential. State of the art production technologies are used to accomplish this objective. To be profitable, orchard farming does not require very large farm areas. In fact, in Poland's fruit growing regions, many farms have the area of 8-15 hectares, and yet, their profitability is very high. Maintaining high profitability and income generating ability of orchard farming involves continuous investments in new farming technologies and intensification thereof. This is possible thanks to accessibility of detailed production know-how and modern technical equipment designed for enhancing the work efficiency and quality of the crops [5].

The aim of this paper was to present the effect of modern apple production technologies on the development of family orchard farming and possible savings in the farm's economic calculation.

\section{Materials and methods}

At the analysed farm situated in the village of Lesznowola (community of Grójec, Poland), the whole area, i.e. 12 hectares, is occupied by apple tree orchards. Most of them are modern double row cultures ensuring high crops and production profitability. The apple varieties grown in the orchard include Golden Delicious, Gala, Camspur, Idared, Szampion, Gloster and Ligol. Orchards are always established from domestic, two-year-old trees with a one-year-old crown. The vast majority of soils at the farm are classified in the $3^{\text {rd }}$ and a small share in the $4^{\text {th }}$ quality class, which facilitates achievement of high crops of ca. 50-60 tonnes of apples per one hectare of orchard with fully fructifying trees. The 
area of the farm is elevated with southern sloping, which prevents freezing of the blossoms during springtime frosts and allows cultivation of thermophilic varieties, including Gala and Red Delicious.

All the cultures at the farm are covered by a drop irrigation system, which ensures better crops. This was particularly evident in 2015 , when very intensive droughts occurred in summer. The farm has the equipment required for apple production and storage. The storage facilities are capable of storing approximately 500 tonnes of apples in controlled atmosphere conditions. Thanks to this, the fruit may be stored after harvest until as long as August of the following year. Apple recipients are companies exporting the fruit to other parts of Europe.

For many years now, the farm has been investing in modern farming technologies, using the EU funds and own resources. Both the access to the EU funds and own resources inspired presentation from the point of view of the orchard farm's owner - of the effects of investing in state of the art equipment and technical solutions within selected apple production technology elements. Detailed analyses covered the influence of the orchard irrigation system as well as the effects of changing the sprayer at the farm as well as the approach to the method used for removal of tree branches from the orchard. The last two technological activities, i.e. orchard spraying and removal of tree branches were taken to consider some aspects of the technological progress implementation in the farm fruit production. The technological progress implementation was compared on the base of the index of technological level, constituting an element of the energy-technological methodology for the analysis of agricultural transformation effectiveness [6]. The index determines the level of technological progress connected with an increasing use of mechanisation in the analysed agricultural / horticultural processes and is given on a scale of $0-100 \%$. According to [6], to calculate the index of technological level $\left(\mathrm{W}_{\mathrm{tl}}\right)$ the following formula was used:

$$
W_{t l}=\frac{E_{m}}{E_{m}+E_{l}} \cdot 100
$$

where $W_{t l}-$ index of technological level, \%;

$E_{m}$ - mechanical energy consumption, MJ;

$E_{l}-$ labour energy consumption, MJ.

Including the needs of the current investigation, the components included in the formula (1) were determined on the base of the measurements carried out at the analysed farm and transformed into usable energy [6] expressed in MJ.

The experiment aimed at determination of the effect of irrigation on the apple tree yield was conducted in summer 2015. The whole area of the farm was irrigated; therefore, the valve supplying water to drop dispensers was cut off in one of the apple tree rows. Throughout the season, one row of apple trees was not irrigated. The experiment included Gloster variety trees. The trees in the orchard part concerned were growing on the third quality class soil and were enhanced on M9 rootstock. The experiment involved harvesting of apples in October from three non-irrigated trees (312 randomly picked fruit were considered) and from three irrigated trees from the adjacent row (also, 312 randomly picked fruit were considered). Subsequently, the fruit was calibrated and weighed. During calibration, the apples were divided into three calibration ranges, which are most frequently applied in trade, i.e. from $60 \mathrm{~mm}$ to $70 \mathrm{~mm}$, from $71 \mathrm{~mm}$ to $80 \mathrm{~mm}$ and above $80 \mathrm{~mm}$.

The effects of irrigation, the effects of installation of a new sprayer and the effects of the tree removal approach were evaluated based on economic calculation, considering the major cost categories and costs of the applied solution. The amounts were stated in the local currency, i.e. Polish zloty - PLN. The PLN - EUR relation was as follows: 1 EUR $\approx 4.3$ PLN.

\section{Results and discussion}

The results / distribution of apples harvested in the irrigation experiment are presented in Fig. 1. It can be stated that the share of fruit, which the highest sale prices can be achieved for (fruit above $70 \mathrm{~mm}$ of diameter), is much higher on irrigated trees.

The share of apples with the diameter above $70 \mathrm{~mm}$ in the overall crop in $\%$ in the non-irrigated orchard: 
$(160 / 312) \cdot 100 \%=51.28 \%$.

The share of apples with the diameter above $70 \mathrm{~mm}$ in the overall crop in $\%$ in the irrigated orchard:

$$
(272 / 312) \cdot 100 \%=87.18 \% .
$$

The presented calculations demonstrate a difference in the yield among the highest top quality crop at the irrigated and non-irrigated orchard. Further calculations were performed to obtain a precise picture of how the presented data translate onto the farm's income. In 2015, the total crop of dessert apples at the discussed farm was app. 500 tonnes. All the apples were locked in controlled atmosphere chambers with sales planned in spring 2016. In spring 2016, the average price, for which the farm sold 60-70 mm diameter apples, was PLN 1, whereas for fruit with the diameter above $70 \mathrm{~mm}$ - PLN 1.7. Therefore, the sale price of top quality apples was $70 \%$ higher as compared with the price of lower quality apples during the given year in the region of the farm's operation.

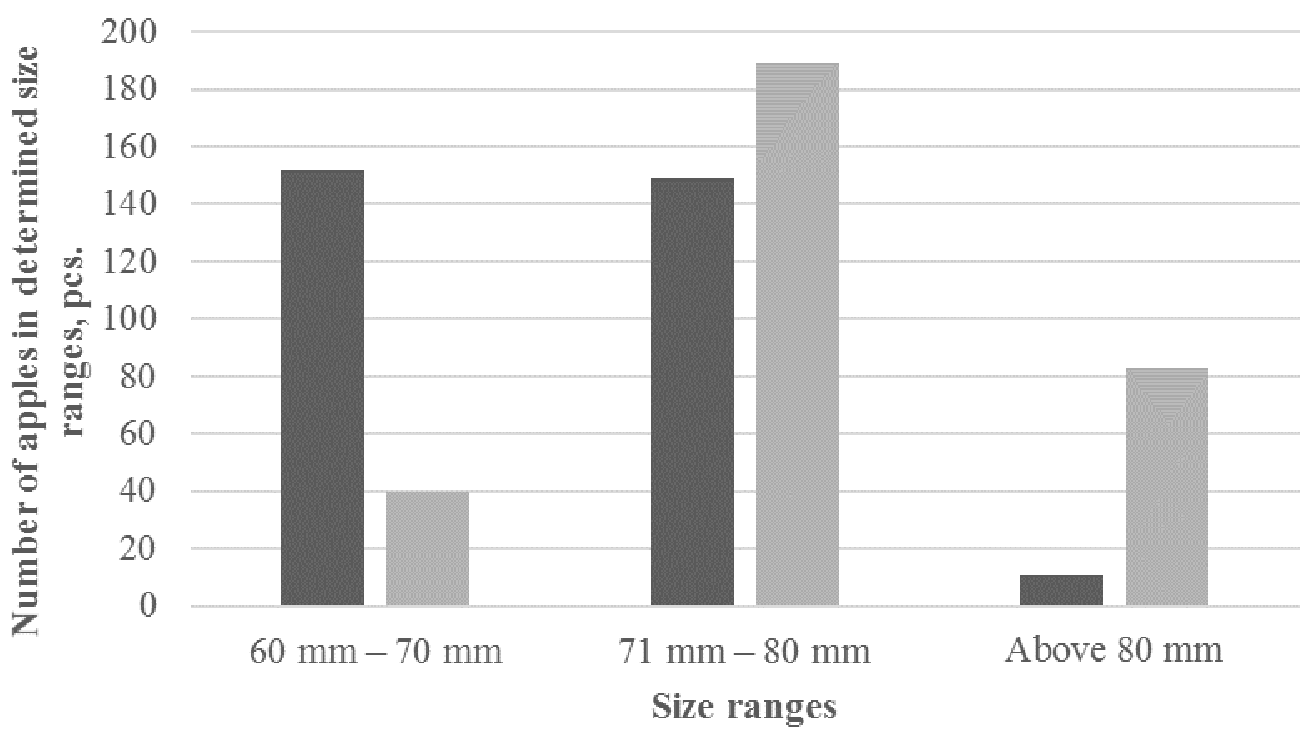

- Fruit from non-irrigated orchard $\quad$ Fruit from irrigated orchard

Fig. 1. Apple calibration results - number of apples in determined size ranges

The total crop of dessert apples produced at the farm in 2015 was app. 500 tonnes. The yield was achieved considering drop irrigation. The share of fruit with the diameter above $70 \mathrm{~mm}$ was $87.18 \%$.

The share of fruit above $70 \mathrm{~mm}$ in total crop:

$$
500000 \mathrm{~kg} \cdot 87.18 \%=435900 \mathrm{~kg} \text {. }
$$

The share of fruit below $70 \mathrm{~mm}$ in total crop:

$$
500000 \mathrm{~kg}-435900 \mathrm{~kg}=64100 \mathrm{~kg} \text {. }
$$

Revenue obtained from the sales of fruit in 2016 amounted to:

$$
(435900 \mathrm{~kg} \cdot 1.7 \mathrm{PLN})+(64100 \mathrm{~kg} \cdot 1 \mathrm{PLN})=741030 \mathrm{PLN}+64100 \mathrm{PLN}=805130 \mathrm{PLN}
$$

If, however, the farm did not have the drop irrigation system and the share of apples with the diameter above $70 \mathrm{~mm}$ amounted to $51.28 \%$ (as in the experiment without irrigation of some of the trees), the sales results would be as follows.

The share of fruit above $70 \mathrm{~mm}$ in total crop:

$$
500000 \mathrm{~kg} \cdot 51.28 \%=256400 \mathrm{~kg} \text {. }
$$

The share of fruit below $70 \mathrm{~mm}$ in total crop:

$$
500000 \mathrm{~kg}-256400 \mathrm{~kg}=243600 \mathrm{~kg} \text {. }
$$


Assuming the 2016 price level, the revenue from sales of fruit could have amounted to:

$(256400 \mathrm{~kg} \cdot 1.7 \mathrm{PLN})+(243600 \mathrm{~kg} \cdot 1 \mathrm{PLN})=435880 \mathrm{PLN}+243600 \mathrm{PLN}=679480 \mathrm{PLN}$

Difference:

$$
\begin{gathered}
805130 \text { PLN }-679480 \text { PLN }=125650 \text { PLN, } \\
(125650 \text { PLN } / 805130 \text { PLN }) \cdot 100 \%=15.6 \% .
\end{gathered}
$$

From the calculation presented it is evident that, as a result of application of the drop irrigation system at the farm, the increase of the farm's profitability may be approximately $15.6 \%$. The above calculations do not include the influence of irrigation onto the quality of fruit storage at the cold store. At the current stage of investigation, it has not been measured precisely, but, based on own observations made so far, a profitability increase at up to $20 \%$ could be expected.

The total cost of constructing the irrigation system, including digging of a deep well at the analysed farm, amounted to approximately PLN 100 thousand. Based on the calculations, the investment cost was returned already during the first year and allowed the farm to be more competitive in the market.

Effects of replacement of the old sprayer at the farm

Due to low efficiency of the ventilator of the old sprayer, the pace of plant protection procedures was app. $4.5 \mathrm{~km} \cdot \mathrm{h}^{-1}$. Purchase of the new sprayer allowed increasing it to ca. $7 \mathrm{~km} \cdot \mathrm{h}^{-1}$. This resulted in shortening of the plant protection procedure and reduction of financial outlays on fuel (diesel fuel) for the tractor.

Calculations regarding the effects of the sprayer replacement.

Based on own investigations, the distances to be driven by the tractor with the sprayer to cover the whole 12-hectare orchard were summed up. The total distance obtained was $34.2 \mathrm{~km}$.

Calculation of the time needed to spray the whole orchard using the old sprayer, at the driving speed of $4.5 \mathrm{~km} \cdot \mathrm{h}^{-1}$, is as follows:

$$
34.2 \mathrm{~km}: 4.5 \mathrm{~km} \cdot \mathrm{h}^{-1}=7.6 \mathrm{~h}=7 \mathrm{~h} \text { and } 36 \mathrm{~min} .
$$

Calculation of the time needed to spray the whole orchard using the new sprayer, at the driving speed of $7 \mathrm{~km} \cdot \mathrm{h}^{-1}$, is as follows:

$$
34.2 \mathrm{~km} \mathrm{:} 7 \mathrm{~km} \cdot \mathrm{h}^{-1}=4.88 \mathrm{~h}=4 \mathrm{~h} \text { and } 53 \mathrm{~min} .
$$

Difference:

$$
7 \mathrm{~h} \text { and } 36 \mathrm{~min} .-4 \mathrm{~h} \text { and } 53 \mathrm{~min} .=2 \mathrm{~h} \text { and } 43 \mathrm{~min} \text {. }
$$

The calculations do not consider the time needed to prepare the working liquid during the plant protection procedure, as it is the same in both cases and does not contribute any new elements into the calculations.

Based on own investigations, the fuel consumption of the New Holland orchard farming tractor during work with the old sprayer was determined at app. 4.5 litre of diesel fuel per 1 working hour, whereas with the new sprayer - at app. 5.5 litre per one working hour.

The cost of spraying 12 hectares of the orchard using the old sprayer (with the diesel fuel price assumed at PLN 4.1 per litre):

$$
\begin{gathered}
7.6 \mathrm{~h} \cdot 4.5 \mathrm{l} \cdot \mathrm{h}^{-1}=34.2 \text { litres, } \\
34.2 \text { litres } \cdot 4.1 \mathrm{PLN} \cdot \mathrm{l}^{-1}=140.22 \mathrm{PLN} .
\end{gathered}
$$

The cost of spraying 12 hectares of the orchard using the new sprayer (with the diesel fuel price assumed at PLN 4.1 per litre):

$$
\begin{gathered}
4.88 \mathrm{~h} \cdot 5.5 \mathrm{l} \cdot \mathrm{h}^{-1}=26.84 \text { litres, } \\
26.84 \text { litres } \cdot 4.1 \mathrm{PLN} \cdot \mathrm{l}^{-1}=110.04 \mathrm{PLN} .
\end{gathered}
$$

Assuming - based on own experience - that 35 plant protection procedures are performed per season, the total cost of diesel fuel for the analysed sprayers is, respectively. 
Old sprayer:

$$
\text { 140.22 PLN } \cdot 35=4907.7 \text { PLN. }
$$

New sprayer:

$$
\text { 110.04 PLN · } 35=3851.4 \text { PLN. }
$$

\section{Difference:}

$$
\text { 4907.7 PLN - 3851.4 PLN = 1056.3 PLN. }
$$

The calculations confirm that purchase of a modern sprayer contributed to shortening the time needed to perform plant protection procedures and reduction of the diesel fuel purchase costs.

The results of the own measurements were taken to calculate and compare the index of technological level $\left(W_{t l}\right)$ for orchard chemical protection, when older and new sprayers were used in the farm. Basing on proper calculation, according to the methodology given by [6], it is possible to indicate that replacement of the old sprayer with a new one at the farm was expressed by increase in the index of technological level from $89 \%$ to $94 \%$. Taking into account the results of the economic analyses it is possible to find that increase in the $W_{t l}$ index by $5 \%$ was associated with 21.5 per cent drop in the total cost of diesel fuel for the analysed new sprayer per season.

\section{Effects of change in the method of tree branch removal from the orchard}

Based on own investigations, the time needed to clear 12 ha of the orchard from tree branches in case of manual removal of tree branches was calculated as follows:

$$
12 \mathrm{ha} \cdot 4 \mathrm{~h} \cdot \mathrm{ha}^{-1}=48 \mathrm{~h}
$$

Based on own investigations, the time needed to clear 12 ha of the orchard from tree branches in case of mechanical branch fragmentation was calculated as follows:

$$
12 \mathrm{ha} \cdot 1.5 \mathrm{~h} \cdot \mathrm{ha}^{-1}=18 \mathrm{~h}
$$

The difference between the time needed to remove tree branches in case of application of the two methods presented above is as follows:

$$
48 \mathrm{~h}-18 \mathrm{~h}=30 \mathrm{~h}
$$

The calculations demonstrate that use of a hammerhead grinder for removal of tree branches from the orchard allowed saving of app. 30 hours.

Removal of tree branches from the orchard is always accompanied by one activity - raking the branches out from under the trees into the space between tree rows. People performing winter trimming of apple trees are not able to control where the branches being cut fall. Consequently, their removal from under the trees to the space between tree rows remains to be done In the past, this activity was performed in the simplest way possible, i.e. by raking them out using plastic rakes. Yet, this activity is highly time consuming. Based on our own observations, one employee is able to rake approximately 1 hectare of orchard during a 10-hour working day.

At the analysed farm, this problem was resolved by introducing a state of the art technology based on a hydraulic branch rake. This is a simple device, usually fitted on the front three-point linkage of the tractor and powered from its hydraulic system. The prerequisite for using the machine is absence of stones under the trees as, otherwise, stones will be raked out together with the branches which may damage the grinder blades. App. 0.5 ha of the orchard area may be raked during one hour of operation of the machine.

The results of calculations performed based on investigations and observations of the branch removal process are summed up below.

Time needed to rake 12 ha of orchard:

$$
10 \mathrm{~h} \cdot \mathrm{ha}^{-1} \cdot 12 \mathrm{ha}=120 \mathrm{~h} .
$$

Time needed to rake 12 ha of orchard using a hydraulic rake:

$$
2 \mathrm{~h} \cdot \mathrm{ha}^{-1} \cdot 12 \mathrm{ha}=24 \mathrm{~h} .
$$

Financial expenditure on raking 12 ha of the apple tree orchard using a rake (cost of human labour at the analysed farm amounted to app. $12 \mathrm{PLN} \cdot \mathrm{h}^{-1}$ ): 
$120 \mathrm{~h} \cdot 12 \mathrm{PLN} \cdot \mathrm{h}^{-1}=1440$ PLN.

Financial expenditure on raking 12 ha of the apple tree orchard using a hydraulic rake (the tractor consumes 4.5 litre diesel fuel per hour; price of diesel fuel: 4.1 PLN $\cdot 1^{-1}$ ):

$$
24 \mathrm{~h} \cdot 4.5 \mathrm{l} \cdot \mathrm{h}^{-1}=1081 \text { of diesel fuel, }
$$

$1081 \cdot 4.1 \mathrm{PLN} \cdot 1^{-1}=442.8$ PLN.

Difference in financial expenditures among the two methods of branch raking:

$$
\text { 1440 PLN - 442.8 PLN = 997.2 PLN. }
$$

The calculations presented have demonstrated the benefits connected with implementation of a modern branch raking method using a hydraulic rake. Next to financial benefits, the time saved is of importance. Full economic analysis requires consideration of the cost related to equipping the farm with the machine. At the analysed farm, return of the investment in a hydraulic rake will occur after app. 5 years.

Results of the own measurements were taken also to calculate the index of technological level $\left(W_{t l}\right)$ for two methods of tree branch removal from the orchard. Basing on the carried out calculation, according to the methodology given by [6], it is possible to find that replacement of the manual method of tree branch raking with mechanical branch raking (using the hydraulic rake) showed increase in the index of technological level from $20 \%$ to $88 \%$. Such results confirm that transition from manual into mechanical kind of work within the considered activity (as a part of fruit production technology) is associated with high increase in the index of technological level, considerable higher than the increase, when some technical solutions are replaced by modern technical solutions, as considered in the case of replacement of the old sprayer with a new sprayer in the investigated farm.

The investigation performed based on the example of a family owned orchard has confirmed the possibility to differentiate the level and structure of labour outlays as a result of implementation of increasingly modern technical solutions in orchard farming [7-9].

Detailed analyses presented in the literature [10] indicate that efficiency of drop irrigation in orchard farming is expressed by a relatively short period of return of the investment costs incurred (on equipping the farm with specialist irrigation systems), which is confirmed by the results of the tests performed at the analysed farm. The production efficiency aspect may show connections with the farm size $[11 ; 12]$; therefore, it is important to continue analyses on a greater number of farms, which will allow determining the effect of the potential, including the farm size, onto the efficiency of changes implemented in orchard production. One of the suggested directions related to enhancing orchard production is creation of producer groups [13], which supports enhancement of competitiveness on the domestic and international fruit market, as well as regular farm resources including their technical equipment [14].

\section{Conclusions}

1. At present, running of a well-developed orchard farm increasingly resembles running an enterprise. So far, a farmer has been perceived as a person who produces, sells and earns money on that. Yet, at the time of increased production costs, falling prices of agricultural produce and the market situation, which all have negative impact onto the financial balance of the farm, the farmer must first of all be a good entrepreneur and have entrepreneurial planning skills.

2. Technical and technological farm modernisation contributes to increased the technological level of fruit production and profitability.

3. Introduction of modern and mechanised apple cultivation technologies has confirmed the possibility to reduce production costs and labour intensity of performing particular procedures.

\section{References}

1. Zmarlicki K., Brzozowski P. Produkcja jabłek w Polsce i innych krajach UE (Production of apples in Poland and other countries). Owoce Warzywa Kwiaty: Fruits Vegetables Flowers, vol. 24, 2010, pp. 26. (in Polish). 
2. Nosecka B. (ed.). Rynek owoców i warzyw - stan i perspektywy (Fruits and vegetables market current state and perspective). Analizy Rynkowe (Market Analysis), Instytut Ekonomiki Rolnictwa i Gospodarki Żywnościowej - Państwowy Instytut Badawczy: Institute of Aricultural and Food Economics - National Research Institute, Warsaw, December 2016, pp. 51. (in Polish).

3. Mazurkiewicz-Pizło A. Innowacyjność działań gospodarstw sadowniczych w regionie Grójca i Warki w aspekcie konkurencyjności regionu (Innovative activity of orchard farms in Grójec and Warka region in terms of the region's competitiveness). Problemy Rolnictwa Światowego Zeszyty Naukowe SGGW: Problems of World Agriculture, vol. 12 (XXVII)/1, 2012, pp. 127-137. (in Polish).

4. Makosz E. Czynniki decydujące o jakości jabłek (Factors affecting apple quality). Wyd. Plantpress: Plantpress Edit., Lublin, 2010, pp. 6-10. (in Polish).

5. Kowalczyk Z. Intensywność produkcji a wyposażenie i wykorzystanie wybranych technicznych środków produkcji w gospodarstwach sadowniczych (Production intensity compared to equipping and use of selected engineering means of production in orchard farms). Inżynieria Rolnicza: Agricultural Engineering, vol. 10(108), 2008, pp. 111-116. (in Polish).

6. Nowacki T. Changes and trends in the quantity and balance of energy consumption in agriculture (general methodology). FAO/ECE/AGRI/MECH Report, No 105, UN, Geneva, 1984, pp. 36.

7. Kowalczyk Z. Poziom i struktura nakładów pracy w wybranych gospodarstwach sadowniczych (Level and structure of labor expenditures in selected fruit-growing farmsteads). Inżynieria Rolnicza: Agricultural Engineering, vol. 11(86), 2006, pp. 209-214. (in Polish).

8. Rorat J., Szeląg-Sikora A. Labour consumption of fruit production on the example of selected farms. Agricultural Engineering, vol. 4(148), 2013, pp. 133-142.

9. Hołownicki R. Miejsce agroinżynierii w rozwoju produkcji ogrodniczej w Polsce (The role of horticultural engineering in development of Polish horticulture production). Inżynieria Rolnicza: Agricultural Engineering, vol. 11(86), 2006, pp. 135-146. (in Polish).

10. Rolbiecki S., Rolbiecki R., Rzekanowski C. Efektywność nawodnień kroplowych u wybranych gatunków roślin sadowniczych (Water use efficiency in drip irrigation of chosen fruit-growing crops). Inżynieria Rolnicza: Agricultural Engineering, vol. 3(45)/1, 2003, pp. 151-160. (in Polish).

11. Pasour E.C. A further note on the measurement of efficiency and economies of farm size. Journal of Agricultural Economics, vol. 32(2), 1981, pp. 135-149.

12. Kulawik J. Wybrane aspekty efektywności rolnictwa (Some aspects of agriculture effectiveness). Zagadnienia Ekonomiki Rolnej: Problems of Agricultural Economics, vol. 1(310), 2007, pp. 3-16. (in Polish).

13. Szeląg-Sikora A. Efektywność produkcji gospodarstw indywidualnych zrzeszonych w sadowniczej grupie producenckiej (Production efficiency in individual farms united in fruitgrowing manufacturers' group). Inżynieria Rolnicza: Agricultural Engineering, vol. 5(123), 2010, pp. 267-273. (in Polish).

14. Gaworski M., Malinowski K. Analiza transformacji gospodarstwa ogrodniczego z uwzględnieniem aspektów technicznych (Analysis of horticultural farm transformation including some technical aspects). Inżynieria Rolnicza: Agricultural Engineering, vol. 9(134), 2011, pp. 41-48. (in Polish). 